
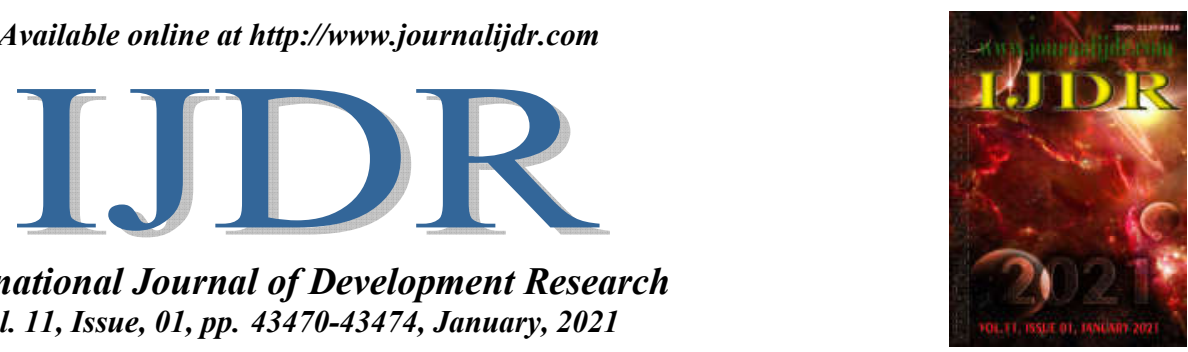

ISSN: 2230-9926

International Journal of Development Research

Vol. 11, Issue, 01, pp. 43470-43474, January, 2021

https://doi.org/10.37118/ijdr.20745.01.2021

\title{
RECENT EPIDEMIC OF COVID-19: A PROSPECT OF CASES AND DEATHS IN THE STATE OF MARANHÃO
}

\author{
Mara Izabel Carneiro Pimentel, Suzane Katy Rocha Oliveira, Ethnary Monteiro de Melo*, \\ Viviane Sousa Ferreira, Mavi Lima Marinho, Marcia Rodrigues Veras Batista, Etiane Conceição \\ Silva Machado, Érica Krogh, Fernanda Rachel Melo e Vidigal do ó, Rosangela Rodrigues Alencar, \\ Cláudia Zeneida Gomes Parente Alves Lima, Vítor Sampaio Câmpelo, Keyllane da Silva Lindoso \\ Duarte, Leandra Campos Silva, Washington Kleber Rodrigues Lima, Maria Zali \\ Borges Sousa San Lucas and Poliana da Silva Rêgo Furtado
}

Ceuma University (UNICEUMA), São Luís - MA

\section{ARTICLE INFO}

Article History:

Received $17^{\text {th }}$ October, 2020

Received in revised form

$19^{\text {th }}$ November, 2020

Accepted $02^{\text {nd }}$ December, 2020

Published online $30^{\text {th }}$ January, 2021

Key Words:

Epidemiology, Confirmed case,

Deaths, Coronavirus.

*Corresponding author:

Ethnary Monteiro de Melo

\begin{abstract}
Objective: To describe the number of confirmed cases and deaths by COVID-19 in the State of Maranhão. Descriptive, documentary and retrospective study, using secondary data extracted from the COVID-19 Epidemiological Bulletin of the State of Maranhão from April 1st to September 30th. The following were considered: confirmed cases of COVID-19, deaths by age group, date of occurrence, associated comorbidities. The data are public and are available in the health system's online bulletins. There were 173,564 confirmed cases and 3,756 registered deaths. The evolution of COVID-19 cases by date was greater on September 2, totaling 1,787 cases in that period. The evolution of deaths by date shows that the months of July and August had the highest rates of death records by COVID-19, with a fall in the month of September. Higher rates of confirmed cases occurred in men. Deaths occurred more in the elderly over 70 years of age. Arterial hypertension and diabetes mellitus were the most comorbidities related to deaths. It is concluded that this research contributes to a greater reflection that COVID-19 has negative proportions and impacts for the population and mainly for the elderly population, where the highest death rates occurred exactly in the elderly.
\end{abstract}

Copyright (C) 2021, Mara Izabel Carneiro Pimentel et al. This is an open access article distributed under the Creative Commons Attribution License, which permits unrestricted use, distribution, and reproduction in any medium, provided the original work is properly cited.

Citation: Mara Izabel Carneiro Pimentel, Suzane Katy Rocha Oliveira, Ethnary Monteiro de Melo et al. "Recent epidemic of covid-19: a prospect of cases and deaths in the state of maranhão", International Journal of Development Research, 11, (01), 43470-43474.

\section{INTRODUCTION}

The World Health Organization (WHO) declared the outbreak of a new Coronavirus in January 2020, called Serious Acute Respiratory Syndrome of Coronavirus 2 (SARS-CoV-2), which was identified in Wuhan (China) in December 2019, being considered a public health emergency of international importance (ESPII) and, by the Ministry of Health (MS) of Brazil, as a public health emergency of national importance (ESPIN), in February 2020 (WHO, 2020; BRASIL, 2020). However, since January 2020, the Ministry of Health has already recommended a preliminary definition for notification of a suspected case of undetermined pneumonia with an epidemiological link, in which it changed the definition of a suspected case and made its immediate notification to the
Center for Strategic Information of up to 24 hours mandatory. National Health Surveillance (CIEVS), as planned for events of public health importance (BRASIL, 2020). Subsequently, the disease was called COVID-19 by the WHO, which, in February 2020, was first detected in Brazil after confirmation in São Paulo of the first case imported from Italy. On March 20, the Ministry of Health announced community transmission nationwide, after the occurrence of autochthonous cases without an epidemiological link to a confirmed case. By May 5, approximately 100 thousand cases and 9,897 deaths had been reported by COVID-19 (WHO, 2020; BRASIL, 2019). O SARS-CoV-2induces, in severe cases, a cytokine storm that ultimately leads to the activation of the coagulation cascade, causing thrombotic phenomena. There is still a strong link between abnormal coagulation parameters (D-dimer and fibrin 
degradation products) and mortality (MEHTA et al., 2020). According to Tang et al. (2020) about $71.4 \%$ of non-survivors and $0.6 \%$ of survivors presented evidence of disseminated intravascular coagulation (DIC), suggesting that DIC is a frequent occurrence of severe COVID-19 (BRASIL, 2019). The disease COVID-19 was initially notified in Brazil in February 2020, and the first death occurred in March 2020. Its spread occurred very quickly, increasing by more than nine thousand deaths in just two months later. Since these deaths refer to people who had a confirmed diagnosis through the positive result of the Polymerase Chain Reaction Test (PCR acronym in English for Polymerase Chain Reaction), in which genetic material of SARS-CoV-2 is detected and establishes the presence of the virus (BRASIL, 2020). The causes of death are based on the death certificate (DO), which is a standard international document that must, in Brazil, always be filled out by a doctor. For the purpose of mortality statistics, the basic cause (CB) is selected, which must be the cause declared in the last line of the medical certificate. $\mathrm{CB}$ is understood as the illness or circumstance of the accident or violence that started the chain of morbid events that led directly to death (BRASIL, 2009). In the case of disease by the SARS-CoV-2 virus, CB should be reported as COVID-19, and clinical suspicion without laboratory results should be declared as suspected of COVID-19. Pre-existing comorbidities responsible for worsening the disease should not be considered $\mathrm{CB}$ of death (WHO, 2020). Because it is a disease that arrived aggressively, affecting several people and with high numbers of deaths, which left the scientific community on the alert looking for treatments and ways to prevent so many deaths, as well as intensifying prevention measures, it is justified to carry out of this research to verify the number of deaths occurred by Covid-19 in 2020 in the State of Maranhão.

\section{METHODS}

Health information systems serve for decision making and help us to plan health strategies, the objective of the present study wasdescribing the number of confirmed cases and deaths as a result of COVID-19 in the State of Maranhão. The study was done with data from the State of Maranhão, it is of the type descriptive, documentary and retrospective, using secondary data extracted from the COVID-19 Epidemiological Bulletin of the state of Maranhão published on the digital platform of the State Department of Health.It was decided to establish a time series because at the present moment, the bulletins are updated daily, however, the clipping of the study gives full possibility of carrying out an adequate analysis and understanding about the situation that the State of Maranhão goes through in relation to new cases and deaths. Since the State started to notify after the first case confirmed by COVID-19 on March 21, 2020, with 2 (two) confirmed cases. Currently, as of December 4, 2020, the state has notified 194,800 cases and a total of 4,330 deaths, that is, by the close of the assessed balance sheet (July) the country had already accounted for more than $60 \%$ of total deaths if we consider today's date. The information used for this study is available on the Portal of the State Department of Health through the Center for Strategic Information on Health Surveillance (CIEVS). The information search period was from April 1 to September 30, 2020. The data were analyzed using the graphs available in the epidemiological bulletin. The variables analyzed were confirmed new cases and deaths notified by age, date of occurrence and associated comorbidities.

\section{RESULTS AND DISCUSSION}

Confirmed cases of COVID-19 in the state of Maranhão: The new coronavirus (SARS-CoV-2) is a subtype of a beta coronavirus of the same subgenus of Middle East Respiratory Syndrome (MERS-CoV). The virus belongs to the Coronaviridae family and causes an infectious disease called COVID-19. Its emergence came with an outbreak in Wuhan, China at the end of December 2019. Shortly after spreading to countries around the world, on March 11, 2020, the World Health Organization (WHO) declared COVID -19 as a pandemic (MARINELLI et al., 2020; BRASIL, 2020). Human coronaviruses (HCoVs) are considered inconsequential pathogens, causing only a "common cold" in healthy people. However, in 2020, two highly pathogenic HCoVs appear Severe Acute Respiratory Syndrome coronavirus (SARS-CoV) and Middle East Respiratory Syndrome coronavirus (MERS$\mathrm{CoV}$ ), which emerged from animal reservoirs causing global epidemics with alarming morbidity and mortality (PAULES et al., 2020). According to the Ministry of Health, the contagion of COVID-19 is very fast, where $20 \%$ of cases may require hospital care because they have difficulty breathing, of these cases approximately $5 \%$ will need ventilatory support to treat respiratory failure. In this context, the most efficient way to fight the coronavirus and try to reduce the contagion, avoiding the collapse of the health system, is to promote social distance and avoid agglomerations, which are nothing more than nonpharmacological measures, that is, they do not involve the use of medicines (BRASIL, 2020). In addition, the pattern of growth in the number of cases and deaths has a sigmoidal character, which is very well described by non-linear regression models. This class of models is used to describe the growth pattern in the most diverse areas of study. In addition to good fit quality, non-linear models have another great advantage, which is the practical interpretation of their parameters (SANTOS et al., 2020). Knowing the epidemiological characteristics such as number of cases and mortality can be useful in adopting preventive measures, contributing to the reduction of deaths and the need to expand the hospital structure (CORRÊA et al., 2020). Thus, figure 1 is presented to demonstrate the number of cases and deaths in the State of Maranhão from April 1 to September 30, 2020. 173,564 cases were confirmed, and the total number of deaths reached 3756 in that period alone.

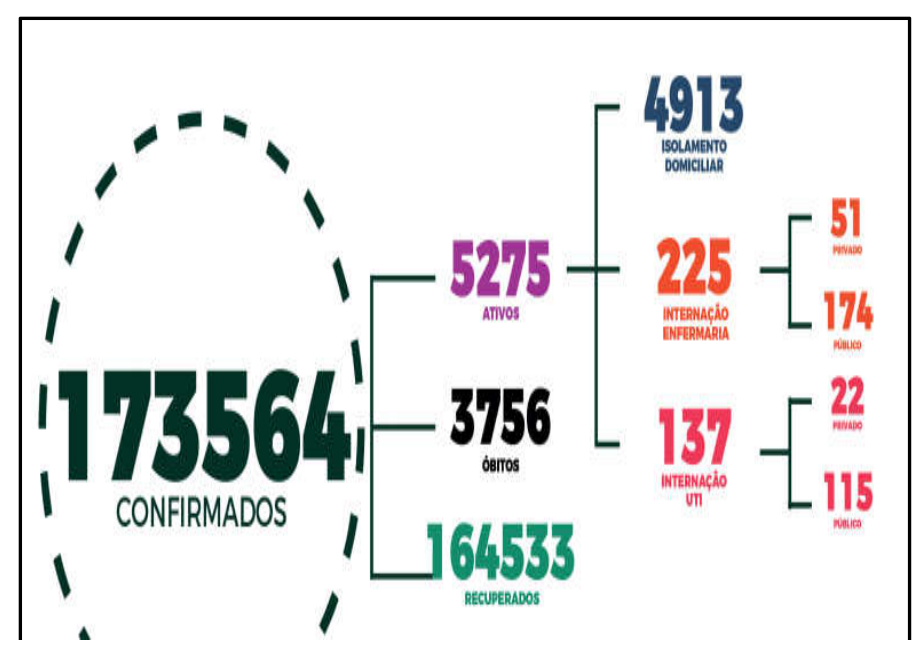

Figure 1. Number of confirmed cases and deaths by COVID-19 between April and September 2020 in Maranhão 
According to Barreto et al. (2020), the recommendations about deaths by COVID-19 should take into account two additional approaches to enable a quick survey and improve knowledge about the mortality situation. Firstly, one should consider as a suspected death of COVID-19 all deaths registered as SRAG from March 2020 and second, as a municipality with probable underreporting of deaths by COVID-19, those with a number of deaths due to pneumonia, respiratory failure, septicemia or ill-defined cause greater than the maximum expected limit for the number of weekly occurrences of each cause. When it comes to death and in large proportions in a given period, a rigorous epidemiological control to reduce these occurrences is imminent. Furthermore, the knowledge about the number of confirmed cases of the disease by COVID-19 is one of the most important data to understand the evolution of this disease.

Deaths in the state of Maranhão: Figure 2 shows the evolution of COVID-19 cases by date and it appears that the largest number of cases made a big jump on September 2, totaling 1,787 cases in that period. According to data from the study by Lana et al. (2020) early diagnosis is an important mechanism for the detection of new cases, strengthening health surveillance for decision-making in investigation, confirmation and disposal of cases. This fact is assumed that the increase in notifications per day could be greater due to testing. When reflecting on the number of cases per date, the study by Silva et al. (2020) in which they reinforce that, if, on the one hand, the data indicate a decrease in the number of active cases, on the other hand, due to the lack of information on laboratory criteria used for notification of cases and number of tests, they suppose that the real disease situation is not evident, with the possibility of underreporting cases.

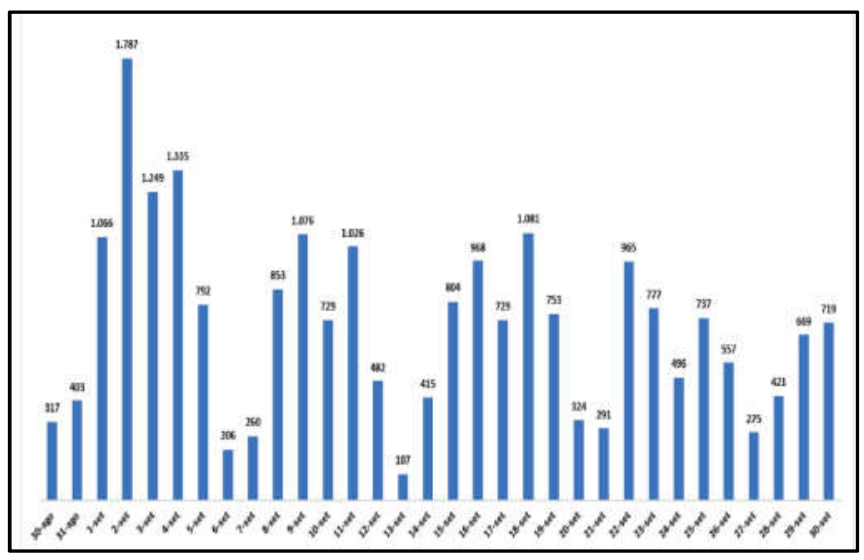

Figure 2. Number of COVID-19 cases in the State of Maranhão, 2020

Regarding the evolution of deaths by date, figure 3 demonstrates that the months of July and August had the highest rates of death records by COVID-19, presenting a decline in September, it is emphasized that the analysis took place between 30 August to September 30, 2020. As the study by Chossani (2020) states that questions have emerged regarding the registration of deaths from causes of death resulting from Covid-19. He noted that some death certificates were issued without prior confirmation of the viral diagnosis for Covid-19, due to the insufficient number of laboratory tests to prove the disease. What is supposed to be this variation of data per day in relation to the number of deaths reported in the State of Maranhão.
The study by França et al. (2020) reinforces that the timely inclusion of confirmed cases of Covid-19 in the Mortality Information System (SIM) can be difficult and timeconsuming, even after the recommendation to medical professionals to indicate in the DO when there is a suspicion that the death has been caused by respiratory disease due to infection by the Sars-CoV-2 virus.

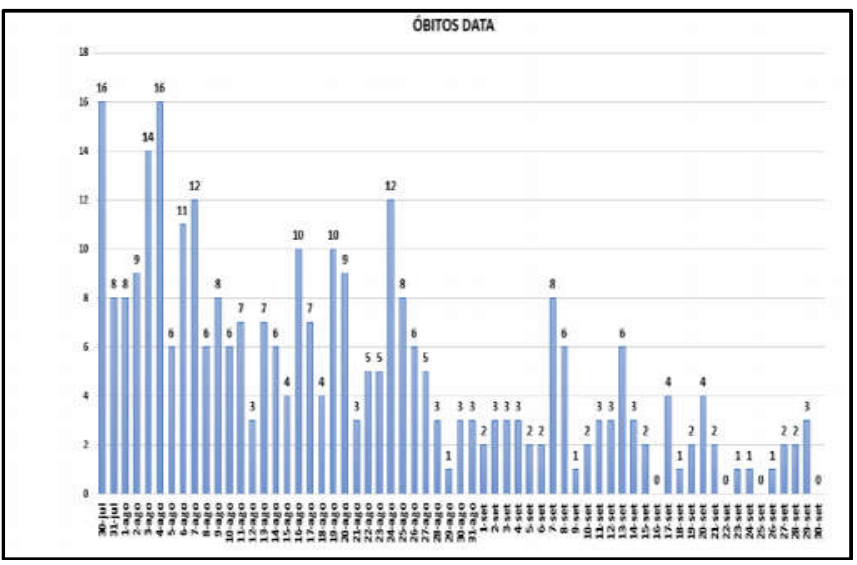

Figure 3. Number of deaths by date of occurrence in the State of Maranhão, 2020

Figure 4 shows the percentage of confirmed cases by sex, showing that the highest indexes of records are male.Authors such as Zeng et al. (2020) point out that although the lower lethality may be associated with a greater perception of the symptoms of the disease and the demand for health services in women, men would only do so in the most severe phases, when the therapeutic resources are generally lower, argue that the higher levels of IgG antibodies in women could partially explain the higher lethality among men. In the study of Lima et al. (2020), which aimed to assess the behavioral aspects and beliefs of the population of Ceará in the face of the COVID-19 pandemic, highlighted that andalthough women are more susceptible to coronavirus contamination, male participants were more negligent and did not voluntarily quarantine. Highlight Gomes, Nascimento, Araújo (2007) who in the social imaginary, man sees himself as an invulnerable being, which contributes to taking less care and exposing himself more to risky situations. What, when analyzing this data available in the epidemiological bulletin, draws our attention to the fact of higher rates of cases in the male population.

\section{- percentual de casos CONFIRMADOS POR SEXO}

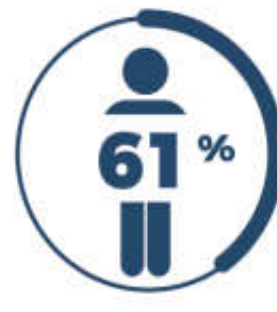

MASCULINO

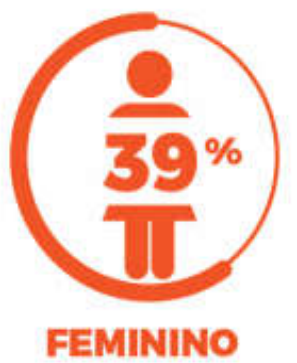

FEMININO
Figure 4. Number of deaths by sex in the State of Maranhão, 2020 
Figure 5 shows deaths by age group and reveals that the majority of deaths occurred in the population over 70 years of age. Therefore, in the study by Barra et al. (2020) associated higher mortality due to COVID-19 in the elderly population or the presence of comorbidities. According to the study by Maciel (2020), the factors associated with deaths occurred more in the elderly, being notified by a public institution, specific diseases / conditions (cardiac, renal, hepatitis, diabetes mellitus, immunological, HIV infection, neoplasms, smoking, neurological) chronic). To consider that people of all age groups are susceptible to infection by COVID-19, as stated by Cheng, Shan (2019). Furthermore, Zhou et al. (2020) highlight that the elderly is considered a factor of concern for contamination by COVID-19, because the increase in age is much more associated with death. Confirming the results presented in the epidemiological bulletin of the State of Maranhão, where the greatest deaths occur in the elderly population. The study by Boccia, Ricciardi, Loannidis (2020) carried out in Italy is similar to the data in the Epidemiological bulletin of the State of Maranhão whose majority of patients who died were on average 80 years old.

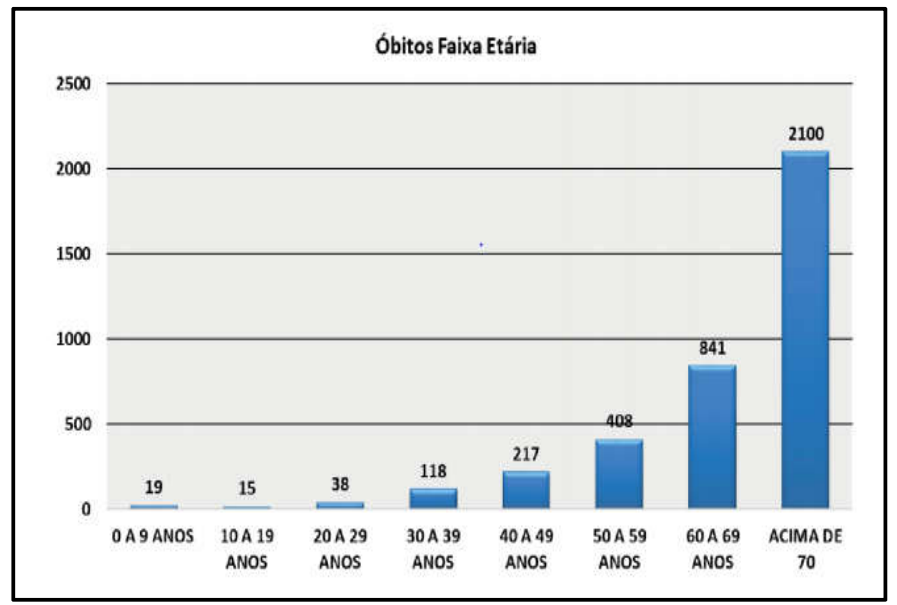

Figure 5. Number of deaths by age group in the State of Maranhão, 2020

Figure 6 shows deaths due to comorbidities, in which it is highlighted that arterial hypertension obtained higher rates of death followed by Diabetes Mellitus. When analyzing the deaths associated with comorbidities, it is clear that the highest rates were arterial hypertension and diabetes Mellitus in the State of Maranhão.

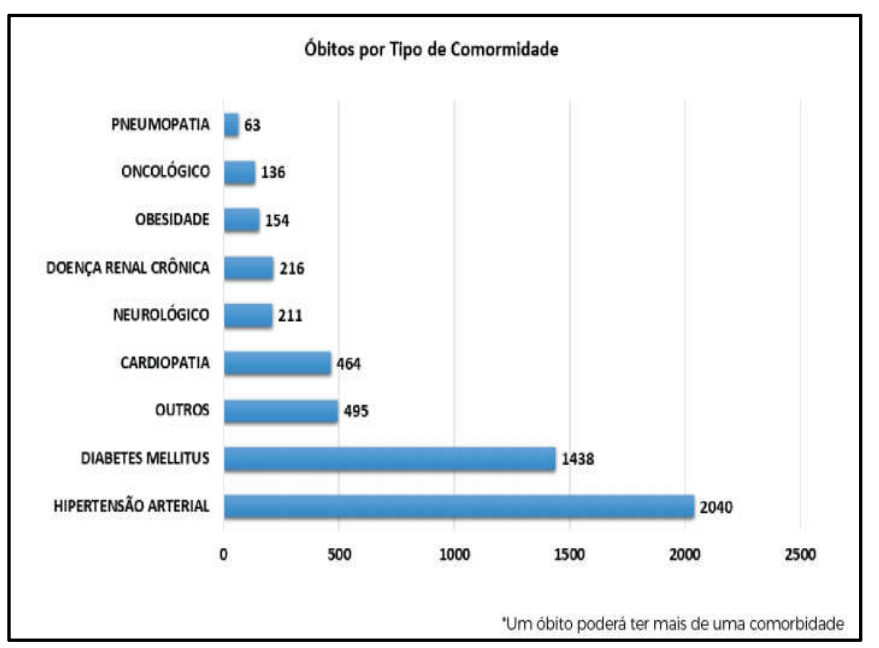

Figure 6. Number of deaths by type of comorbidities in the State of Maranhão, 2020
Thus, the study by Alkundi et al. (2020) who realized that it was not the fact of being hospitalized in a public or private institution that determined the outcome "death", but rather, the conditions prior to entering the health system, including the comorbidities associated with COVID-19, such as smoking, diabetes mellitus, hypertension and obesity. According to Lira, Monteiro (2017), the comorbidities revealed by the deaths by COVID-19 further deepen the immense gap between the realization of health as a right for all. With the Pandemic it became evident the need to create legal mechanisms to fully finance the Unified Health System, so that the Brazilian Nation is more prepared for the next situations of health crisis, predictable in an increasingly globalized world.

\section{Conclusion}

The analyzes of the epidemiological bulletin with the inclusion of data on cases and deaths by Covid-19 demonstrate that its greatest occurrence was in the elderly, with the highest rate of comorbidity being arterial hypertension. Higher number of cases in the male population. Our results support the hypothesis that the increase in deaths in the elderly population may be associated with the COVID-19 pandemic. Above all, there was also a probable underreporting of cases when compared by day of occurrence according to the notification that could indicate an even greater increase in both confirmed cases and in the number of deaths. This research contributed to the reflection that COVID-19 has negative proportions and impacts for the population and especially for the elderly, who through the data analyzed, was observed to be the most affected public, resulting in greater deaths.

\section{REFERENCES}

Alkundi, A .; Mahmoud, I .; Musa, A .; Naveed, S .; Alshawwaf. M. Clinical characteristics and outcomes of COVID-19 hospitalized patients with diabetes in the United Kingdom: a retrospective single center study. Diabetes Res Clin Pract., 2020.

Barra, RP; Moraes, EN; Garden, AA; Oliveira, KK; Bonatti, PCR; Issa, AC The importance of the correct management of the chronic condition in Primary Health Care for coping with COVID-19 in Uberlândia, Minas Gerais. PHC in Review, v. 2, n. 1, p. 38-43, 2020.

Barreto, ML; Barros, AJD; Carvalho, MS; Codeço, CT; Hallal, PRC; Medronho, RA What is urgent and necessary to subsidize policies to deal with the COVID-19 pandemic in Brazil? RevistaBrasileiraEpidemiologia, v. 23, 2020.

Boccia, S.; Ricciardi, W.; Ioannidis, JPA What Other Countries Can Learn from Italy During the COVID-19 Pandemic. JAMA Intern Med. 2020.

Brazil. Ministry of Health. Coronavirus panel. 2020. Available at: https://covid.saude.gov.br. Accessed on: 25 de nov. 2020.

Brazil. Ministry of Health. Federal Council of Medicine. Brazilian Center for Disease Classification. The death certificate: a necessary and important document. Brasília: Ministry of Health; 2009. 38 p.

Brazil. Ministry of Health. Health Surveillance Secretariat. Special Epidemiological Bulletin. COECOVID19. Apr 26 2020.

Brazil. Ministry of Health. Ordinance No. 188, of February 3, 2020. Federal Official Gazette. Brazil; 2020. Available at:http://www.in.gov.br. Accessed on:25 de nov. 2020. 
Brazil. Ministry of Health. Secretariat for Epidemiological Surveillance. Epidemiological Bulletin 4 of 01/22/2020. New coronavirus (2019-CoV). Brazil; 2020. Available at:https://www.saude.gov.br. Accessed on: 25 de nov. 2020.

Brazil. Ministry of Health. Secretariat for Epidemiological Surveillance. Epidemiological Bulletin 13 of 04/20/2020. Center for Public Health Emergency Operations / Coronavirus Diseases 2019 (COE-COVID19). Epidemiological situation. Coronavirus disease, 2019. Available at:https://portalarquivos.saude.gov.br. Accessed on: 25 de nov. 2020.

Cheng, ZJ; Shan, J. Novel coronavirus: where we are and what we know. Infection, v. 48, n. 34, p. 155-163, 2020.

Chossani, FW.The death record in Covid-19 times. São Paulo: Association of Natural People Registrars of the State of São Paulo, 2020.

Corrêa, PRL; Ishitani LH; Abreu, DMX; Teixeira, RA; Marinho, F.; França, EB.The importance of surveillance of cases and deaths and the epidemic of COVID-19 in Belo Horizonte, 2020. RevistaBrasileira de Epidemiologia, v. 23, 2020.

France, EB et al. Deaths due to Covid-19 in Brazil: how many are there, and which are being identified? Brazilian Journal of Epidemiology, v. 23, 2020.

Gomes, R.; Nascimento, EF; Araújo, FC Why do men seek health services less than women? The explanations of men with low education and men with higher education. Public Health Notebook, vol. 23, n. 3, p. 565-574, 2007.

Lana, RM; Coelho, FC; Gomes, MFC; Cruz, OG; Bastos, LS; Villela, DAM; Codeço, CT Emergence of the new coronavirus (SARS-CoV-2) and the role of national surveillance in timely and effective health. Public Health Notebook, v.36, n. 3, p. 04-24, 2020.

Lima, DLF; Dias, AA; Rabelo, RS; Cruz, ID; Costa, SC; Nigri, FMN; Neri, JR COVID-19 in the state of Ceará, Brazil: behaviors and beliefs in the arrival of the pandemic. Ciência\&SaúdeColetiva, v. 25, n. 5, p. 15751586, 2020.

Lira, P.; Monteiro, L. Violence, urbanization and human development: a spatial analysis in Espírito Santo municipalities. In: Marguti, BO; Costa, MA; Silva, PC V, organizers. Territories in numbers: inputs for public policies from the analysis of the MHDI and IVS of municipalities and Units of the Brazilian Federation, Brasília: IPEA; INCT; P. 243-70, 2017.

Maciel, EL; Jabor, P.; Júnior, EG; Sá, RT; Lima, RCD; Santos, BR; Lira, P.; Bussinguer, ECA; ZANDONADE, E. Factors associated with hospital death due to COVID19. Epidemiol. Health Service, Brasília, v. 29, n. 4, p. 413, 2020.
Marinelli, KA; Lawrence, R. Michael. Response to Letters to the Editor about the Safe Handling of Containers of Expressed Human Milk in all Settings During the SARSCoV-2 (COVID-19) Pandemic. Journal of Human Lactation, v. 36, n. 3, 2020.

Mehta, P.; Mcauley, DF; Brown, M.et al. COVID-19: consider cytokine storm syndromes and immunosuppression. Lancet. v. 395, p. 1033-1034, 2020.

Paules, CI, Marston, HD, Fauci, AS Coronavirus infectionsmore than just the common cold. Jama, v. 323, n. 8, p. 707-708, 2020.

Santos, ALP; De Figueiredo, MPS; Ferreira, TAE; GomesSilva, F .; Moreira, GR; Silva, JE, De Freitas, JR Analysis and forecasting of the evolution of COVID-19 death numbers in the state of Pernambuco and Ceará using regression models. Research, Society and Development, v. 9 , n. 7 , p. 1-24, 2020 .

Silva, JPB; Costa, LNC; Monteiro, TAS; Pinto, TO; Portela, NLC Epidemiological analysis of confirmed cases of COVID-19 in Caxias, Maranhão, Brazil. Infection and Health Prevention Magazine, v. 6, p. 1-9, 2020.

Tang, N.; Bai, H.; Chen, X.; Gong, J.; Li, D.; Sun, Z. Anticoagulant treatment is associated with reduced mortality in patients with severe coronavirus disease in 2019 with coagulopathy. J ThrombHaemost, v. 18, p. 1094-1099, 2020.

World Health Organization. International Guidelines for Certification and Classification (Coding) of COVID-19 as cause of death. Geneva: World Health Organization; Apr 202020

World Health Organization. Naming the coronavirus disease (COVID-19) and the virus that causes it. World Health Organization; 2020. Available at:https: //www.who. Accessed on Nov. 282020.

World Health Organization. WHO Director-General's statement on IHR Emergency Committee on Novel Coronavirus (2019-nCoV). Health Emergency of International Concern declared. 2020. Available at:https://www.who.int. Accessed on: Nov. 282020.

Zeng, H. et al. Antibodies in infants born to mothers with COVID-19 pneumonia. Jama, v. 323, n. 18, p. 1848-1849, 2020.

Zhou, F .; Yu, T .; Du, R .; Fan, G .; Liu, Y .; Xiang, J .; Wang, Y .; Song, B .; Gu, X .; Guan, L. et al. Clinical course and risk factors for mortality of adult inpatients with COVID-19 in Wuhan, China: a retrospective cohort study. Lancet., V. 20, 2020. 